\title{
Project-based Learning and Library Access towards Writing Achievement of the Students
}

\author{
Sri Endah Kusmartini*
}

English Department - Sriwijaya State Polytechnic, South Sumatera, Indonesia

Corresponding Author: Sri Endah Kusmartini, E-mail: sriendahkusmartini@yahoo.com

\section{ARTICLE INFO}

\section{Article history}

Received: January 04, 2018

Accepted: March 13, 2018

Published: July 01, 2018

Volume: 7 Issue: 4

Advance access: May 2018

Conflicts of interest: None

Funding: None

\begin{abstract}
Writing skill is one of the language skills that should be mastered by the students of English department. It is believed that Project-based learning in writing class encourages the students to work autonomously and responsibly in producing the manuscripts. It is also believed that library access has a central role in the success of gaining the goal. Therefore, the paper aims at exploring the influence of Project-based Learning and Library Access towards Writing Achievement of the Students. The objectives of this current research were to investigate the correlation between Project-based Learning and Writing Achievement of the Students; the correlation between Library Access and Writing Achievement of the Students; the correlation between Project-based Learning and Library Access; and the inffluence of Project-based Learning and Library Access towards Writing Achievement of the Students. The instruments used in this research were the measure of Project-based Learning and the measure of Library Access. The scores of writing used to illustrate the writing achievement of the students were taken from the archive of English Department Sriwijaya State Polytechnic. Pearson Product Moment Correlation and Multiple Regressions were used to examine the hypotheses. The results showed that there was a significant correlation between Project-based Learning and Writing Achievement of the Students; there was a significant correlation between Library Access and writing achievement of the students; there was a significant correlation between Project-based Learning and Library Access; Projectbased Learning and Library Access influenced writing achievement of the students significantly. Therefore, it is suggested to continue Project-based Learning in writing class and provide better library access to the students so that the writing achievement can be developed.
\end{abstract}

Key words: Project-based Learning, Library Access, Writing Achievement of the Students

\section{INTRODUCTION}

Writing skill is one of the language skills that should be mastered by the students of English Department. Therefore, it should be found out the best way to learn it. Project-based learning is one of the learning models that can be considered to achieve the skill. In Project-based Learning, the students develop many good characters like autonomy and responsibility (Thomas, Mergendoller \& Michaelson, 1999). Of course, the students who have those characters will try their best to achieve the goals. The question arose whether there was a significant correlation between the variable of Project-based Learning as perceived by the students and the variable of Writing Achievement of the Students. By understanding the position of Project-based Learning model towards writing achievement of the students, the management will be able to determine whether to continue this learning model or to change it with other learning models that can improve writing achievement of the students.

Another factor which is believed having a central role in the success of accomplishing the goal is Library Access. Diem (2012) mentions that the library is the center of knowledge and science and together with other components support educational activities in all level of education. The question also arose whether there was a significant correlation between the variable of Library Access as perceived by the students and the variable of Writing Achievement of the Students. It is very important to answer this question because by recognizing the correlation between them, the management will understand whether to continue utilizing the library to support the students' activities especially in order to improve writing achievement of the students or not.

Next, the researcher also wanted to find out whether there was a significant correlation between the variable of Project-based Learning as perceived by the students and the variable of Library Access as perceived by the students. This question is very important to be answered so it can be decided whether it is necessary or not for the management to support the students with good access to the library when Project-based learning is employed in the classrooms.

Finally, the researcher wanted to find out whether the variable of Project-based Learning as perceived by the students and the variable of Library Access as perceived by the 
students influenced Writing Achievement of the Students significantly. By recognizing the influence of both Project-based Learning and Library Access towards writing achievement of the students, the management can think far beyond whether to continue Project-based learning and at the same time provide better library access to the students or not in writing classes.

The following were the hypotheses of this current research. Ho1) There was no significant correlation between Project-based Learning and Writing achievement of the students of English Department Sriwijaya State Polytechnic; Ha 1) there was a significant correlation between Project-based Learning and Writing achievement of the students of English Department Sriwijaya State Polytechnic; Ho 2) There was no significant correlation between Library Access and Writing achievement of the students of English Department Sriwijaya State Polytechnic; Ha 2) there was a significant correlation between Library Access and Writing achievement of the Students of English Department Sriwijaya State Polytechnic; Ho 3) There was no significant correlation between Project-based Learning and Library Access; Ha 3) there was a significant correlation between Project-based Learning and Library Access; Ho 4) Project-based Learning and Library Access did not influence Writing achievement of the Students significantly; Ha 4) Project-based Learning and Library Access influenced Writing Achievement of the students significantly.

\section{LITERATURE REVIEW}

It has been mentioned above that Project-based Learning is believed to have the ability to increase autonomy and the sense of responsibility of the students (Thomas, Mergendoller \& Michaelson, 1999). Moreover, Project-based Learning also encourages the students to work interactively, confidently in solving the problems (Blumenfeld, et al., 1991), and collaboratively (Moursund, 1999), starting from making a plan, implementing and evaluating the project that has been determined (Westwood, 2008). Bell (2010) mentions that Project-based learning is a student-centered learning; it gives a chance for each student to work actively to complete the project starting from generating the questions (Bell, 2010), designing authentic project (Thomas, Mergendoller, \& Michaelson, 1999) independently (Blumenfeld et al., 1991), doing in-depth investigation towards the project (Harris \& Kats, 2001), solving the problem, and making decision (Thomas, Mergendoller, \& Michaelson, 1999). The roles of the teachers are to facilitate, mediate and supervise the activities of each student (Bell, 2010). It is not necessary for the teachers to use rigid lesson plan because the students can figure out their own procedures to answer the questions for the project they choose (Harris \& Katz, 2001). Bottoms and Webb (1998) state that this kind of learning model develops the motivation of the students because they feel actively involved in their own learning, and produce complicated and high-quality work; furthermore, this kind of learning model develops the ability of the students to work. Moreover, Bottoms and Webb (1998) mention that Project-based Learning Model implemented in the classroom makes the students eager to attend the class regularly, participate actively, and do the project willingly. It is hoped that good characters encouraged by Project-based learning model will contribute positively to writing achievement of the students. In terms of Project-based Learning, Mergendoller and Thomas (2000) reported that a middle school in Maine using a Project-based learning approach got significant increases in all achievement areas on the Maine Educational Assessment battery after only one year using the Project-based Learning approach.

The library as a supporting facility provided by the school also has an important role. Its main function is to manage all sources of information owned by the library so that it can give a good contribution to its users (Diem, 2012). Newmann, Celano, Greco, and Shue (2001) confirm that the management of the library should work seriously because the existence of the library influences the community to visit it. The people who have sufficient access towards the library tend to read a wide range of books (Topping, et al., 2003). Therefore, it is believed that the library access should be opened widely for each element in school. Diem (2012) mentions that some of the factors that make students come and visit the library are availability of information, communication and Technology (ICT); the number of the books; new books available; and duration of service. These factors should be considered by the management so that the library access will give a significant contribution to the student achievement. A research conducted by Foese (1997) showed that the difference in terms of the reading score of the students is influenced by the number of the books available in the school library and the high frequency of book lending.

\section{METHOD}

In this current research, the researcher conducted a survey research. The population was the students of English Department Sriwijaya State Polytechnic. The number of the sample was 60 which were taken randomly. There were two independent variables of this current research; they were the variable of Project-based Learning (PBLs) and the variable of Library Access (LAs). Meanwhile, the dependent variable of this current research was Writing Achievement of the Students (WAs).

The data about the variable of Project-based Learning and the data about the variable of Library Access were collected through questionnaires which were delivered to the respondents. The first questionnaire was about the perceptions of the respondents about Project-based Learning that had been implemented in writing classrooms of English Department Sriwijaya State Polytechnic. To obtain the data, the researcher asked the respondents to give perceptions about Project-based Learning that had been implemented in writing classrooms of English Department Sriwijaya State Polytechnic by determining the level of Agreement ranging from 1(Strongly Disagree) to 5 (Strongly Agree). The number of the item was 22. The lowest possible score was 22 and the highest possible score was 110 .

The second questionnaire was about the perceptions of the respondents about access to the library of English Department Sriwijaya State Polytechnic. To obtain the data, the 
researcher asked the respondents to give perceptions about access to the library of English Department Sriwijaya State Polytechnic by determining the level of agreement ranging from 1 (Strongly Disagree) to 5 (Strongly Agree). The number of the item was 18 . The lowest possible score was 18 and the highest possible score was 90 .

Writing scores used to illustrate the writing achievement of the students were taken from the archive of English Department Sriwijaya State Polytechnic.

To find out the frequency and the percentage, the data were analyzed by using descriptive statistic analyses. To investigate the correlation among the variables, the data were analyzed by using Pearson Product Moment Correlation Coefficient. To investigate the influence and the contribution of independent variables towards dependent variable, the data were analyzed by using Multiple Regressions.

\section{RESULTS AND DISCUSSION}

\section{Results}

The following were the results of the research. It started with the score distribution of each variable. Next, the correlations among the variables were described. Finally, the influence and the contribution of Project-based Learning and Library Access towards Writing Achievement of the Students were described in detail.

Table 1 showed the score distribution of each variable. The first variable was Project-based learning as perceived by the students of English Department Sriwijaya State Polytechnic. The second variable was Library Access as perceived by the students of English Department Sriwijaya State Polytechnic. The last variable was writing achievement of the students of English Department Sriwijaya State Polytechnic.

The table below showed the perception of the respondents about Project-based Learning (PBLs) as implemented in writing classes, the perception of the respondents about Library Access, and Writing Achievement of the Students. The number of the respondents who perceived Project-based learning was 60 . The mean was 78.87 . The median was 80.50. The standard deviation was 9.982. The ratio of Skewness was (-0.344/0.309) -1.1. It means that the ratio of Skewness was between -2 and 2 ; therefore, it can be concluded that the data were distributed normally. The minimum score was 62 , and the maximum score was 96 .

The number of the respondents who perceived about Library Access was 60. The mean was 70.42. The median was 69.00 . The standard deviation was 5.861 . The ratio of
Skewness was $(0.224 / 0.309) 0.72$. It means that the ratio of Skewness was between -2 and 2 ; therefore, it can be concluded that the data were distributed normally. The minimum score was 61 , and the maximum score was 80 .

The number of the respondents was 60 . The mean of writing score was 77.05. The median was 80.00 . The standard deviation was 6.258 . The ratio of Skewness was $(-0.254 / 0.309)-0.82$. It means that the ratio of Skewness was between -2 and 2; therefore, it can be concluded that the data were distributed normally. The minimum score was 67 , and the maximum score was 85 .

Table 2 showed the correlation among the variables. First, the correlation between Project-based learning (PBLs) which was implemented in the class of Writing as it was perceived by the respondents and writing achievement of the students (WAs) was described in detail based on the table. Next, the correlation between Library Access (LAs) and Writing Achievement of the Students was described. Finally, the correlation between Project-based learning which was implemented in the class of writing as it was perceived by the respondents and Library Access was described in detail.

The table below showed that the correlation between Project-based Learning which was implemented in the class of Writing as it was perceived by the respondents and Writing Achievement of the Students was 0.667 with the probability value 0.000 which was lower than the alpha level $(0.000<0.05)$. It means that Ho 1$)$ was rejected and $\mathrm{Ha}$ 1) was accepted. Therefore, it can be concluded that there was a significant correlation between Project-based learning which was implemented in writing class as it was perceived by the respondents and Writing Achievement of the Students.

Next, the table also showed that the correlation between Library Access and Writing Achievement of the Students was 0.514 with the probability value 0.000 which was lower than the alpha level $(0.000<0.05)$. It means that Ho 2) was rejected and Ha 2) was accepted. Therefore, it can be concluded that there was a significant correlation between Library Access and Writing Achievement of the Students.

Finally, the table below showed that the correlation between Project-based Learning which was implemented in the class of Writing as it was perceived by the respondents and Library Access was 0.684 with the probability value 0.000 which was lower than the alpha level $(0.000<0.05)$. It means that Ho3) was rejected and Ha3) was accepted. Therefore, it can be concluded that there was a significant correlation between Project-based Learning which was implement-

Table 1. Score distribution of each variable

\begin{tabular}{lcccccccc}
\hline Variable & N & Mean & Median & Standard deviation & Skewness & $\begin{array}{c}\text { Standard error of } \\
\text { skewness }\end{array}$ & Minimum & Maximum \\
\hline PBLs & 60 & 78.87 & 80.50 & 9.982 & -0.344 & 0.309 & 62 & 96 \\
LAs & 60 & 70.42 & 69.00 & 5.861 & 0.224 & 0.309 & 61 & 80 \\
WAs & 60 & 77.05 & 80.00 & 6.258 & -0.254 & 0.309 & 67 & 85 \\
\hline
\end{tabular}

PBLs (Project-based learning as perceived by the students)

LAs (Library access as perceived by the students)

WAs (writing achievement of the students) 
ed in writing class as it was perceived by the respondents and Library Access.

Table 3 and table 4 described the influence and the contribution of independent variables towards dependent variable.

Simultaneously, the correlation between Project-based Learning which was implemented in writing class as it was perceived by the respondents added to Library Access towards Writing Achievement of the Students was 0.672. The $\mathrm{R}$ Square was 0.451 . It means that the percentage of the contribution of Project-based Learning which was implemented in writing class as it was perceived by the respondents added to Library Access towards Writing Achievement of the Students was $45.1 \%$.

The table also showed that F-obtain was 23.423 which was bigger than F-table $(23.423>3.159)$ and the significant was smaller than the alpha level $(0.000<0.05)$. It means that Ho4) was rejected and Ha4) was accepted. Therefore, it can be concluded that simultaneously Project-based learning which was implemented in writing class as it was perceived by the respondents and Library Access influenced Writing Achievement of the students significantly.

Table 2. Correlation among the variables

\begin{tabular}{|c|c|c|c|}
\hline & PBLs & LAs & WAs \\
\hline \multicolumn{4}{|l|}{ PBLs } \\
\hline Pearson correlation & 1 & $0.684 * *$ & $0.667 * *$ \\
\hline Sig. (2-tailed) & & 0.000 & 0.000 \\
\hline $\mathrm{N}$ & 60 & 60 & 60 \\
\hline \multicolumn{4}{|l|}{ LAs } \\
\hline Pearson correlation & $0.684 * *$ & 1 & $0.514 * *$ \\
\hline Sig. (2-tailed) & 0.000 & & 0.000 \\
\hline $\mathrm{N}$ & 60 & 60 & 60 \\
\hline \multicolumn{4}{|l|}{ WAs } \\
\hline Pearson correlation & $0.667 * *$ & $0.514 * *$ & 1 \\
\hline Sig. (2-tailed) & 0.000 & 0.000 & \\
\hline $\mathrm{N}$ & 60 & 60 & 60 \\
\hline
\end{tabular}

\section{Discussion}

The significant correlation between the variable of Project-based Learning which was implemented in writing class as it was perceived by the respondents and the variable of Writing Achievement of the Students shows that the more Project-based Learning was implemented in writing class, the higher the Writing Achievement of the Students. Therefore, if the teachers want to improve writing achievement of the students, the teachers should consider implementing Project-based Learning as one of the learning models in the classroom.

The current research also showed that there was a significant correlation between the variable of Library Access and the variable of Writing Achievement of the Students. It shows that the better the library access of the school, the higher the writing achievement of the students. Therefore, if the teachers want to improve writing achievement of the students, the teachers together with other management should open the access to the library as one of the supporting facilities in school widely.

The significant correlation between the variable of Project-based Learning which was implemented in writing class as it was perceived by the respondents and the variable of Library Access shows that the teachers who want to encourage the students to work autonomously in Project-based Learning should consider Library Access as one of the supporting facilities in the school. The more Project-based Learning is implemented in the classroom, the more the need to Library Access.

The research also showed that simultaneously the variable of Project-based Learning which was implemented in writing class as it was perceived by the respondents added to the variable of Library access correlated significantly towards writing achievement of the students. It means that if the teachers want to improve writing achievement of the students, they should simultaneously consider implementing Project-based Learning as one of the learning models and the Library Access as one of the supporting facilities in school in their planning before teaching and learning process occurred in the classroom.

This current research also proved that simultaneously the variable of Project-based Learning added to the variable of

Table 3. Model summary ${ }^{\mathrm{b}}$

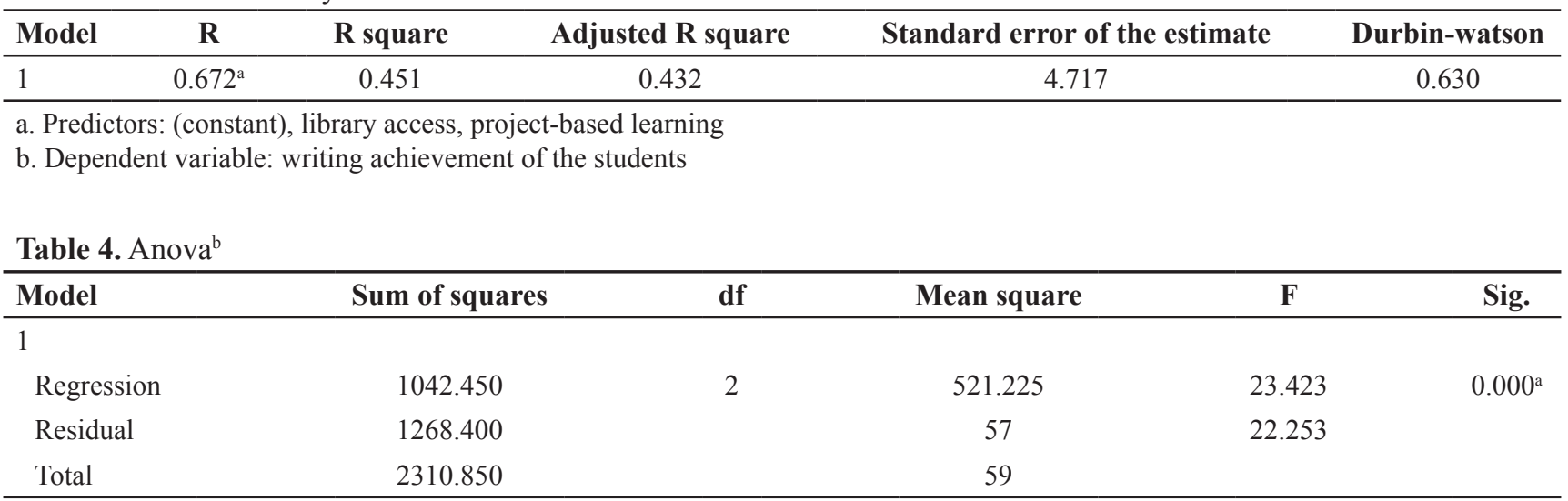

a. Predictors: (constant), library access, project-based learning

b. Dependent variable: writing achievement of the students 
Library Access influenced significantly and gave $45.1 \%$ contribution to writing achievement of the students. It means that if the management and the teachers want to improve the writing achievement of the students, they should consider the use of Project-based Learning and support it with better library access. It also means that there were other factors $(54.9 \%)$ that also influenced and gave the contribution to writing achievement of the students which were not investigated in this current research. Therefore, the teachers of writing together with other teachers and the management in English Department Sriwijaya State Polytechnic should consider other factors that may influence and contribute to writing achievement of the students which were not investigated in this current research.

\section{CONCLUSION AND SUGGESTION}

\section{Conclusions}

There was a significant correlation between the variable of Project-based Learning which was implemented in writing class as it was perceived by the students and the variable of Writing Achievement of the Students. There was a significant correlation between the variable of Library Access as it was perceived by the students and the variable of Writing Achievement of the Students. There was a significant correlation between the variable of Project-based Learning which was implemented in writing class as it was perceived by the students and the variable of Library Access as it was perceived by the students. The research also showed that simultaneously the variable of Project-based Learning which was implemented in writing class as it was perceived by the students added to the variable of Library Access as it was perceived by the students correlated significantly towards the variable of Writing Achievement of the Students. This current research also proved that the variable of Project-based Learning as perceived by the students added to the variable of Library Access as perceived by the students influenced significantly and gave $45.1 \%$ contribution towards the variable of Writing Achievement of the Students. There were other factors $(54.9 \%)$ that also influenced and gave the contribution to writing achievement of the students which were not investigated in this current research.

\section{Suggestions}

The teachers who want to encourage the students to work autonomously in Project-based Learning should consider Library Access as one of the supporting facilities in English Department Sriwijaya State Polytechnic. The teachers should continue the use of Project-based Learning in the classroom to improve writing achievement of the students. The teachers together with the management should open the access to the library as one of the supporting facilities widely in order to improve the writing achievement of the students. The teachers who want to improve writing achievement of the students should consider implementing Project-based Learning as one of the learning models and the library access as one of the supporting facilities partially and simultaneously in their planning before teaching and learning process occurred in the classroom. The teachers of writing together with other teachers and the management should consider other factors that may influence and contribute to writing achievement of the students which were not investigated in this current research. It is a quantitative research. This kind of research only proves the hypotheses and answer yes/no questions. Therefore, it is suggested to continue the research in this area with qualitative one to answer the how and why questions.

\section{REFERENCES}

Bell, S. (2010). Project-based learning for the $21^{\text {st }}$ century: Skills for the future. A Journal of Educational Strategies, Issues and Ideas, 83(2), 39-43.

Blumenfeld, P., Soloway, E., Marx, R., Krajcik, J., Guzdial, M., \& Palincsar, A. (1991). Motivating project-based learning: Sustaining the doing supporting the learning. Educational Psychologist, 26 (3\&4), 369-398.

Bottoms, G., \& Webb, L.D. (1998). Connecting the curriculum to real life and breaking ranks: Making it happen. Reston, VA: National Association of Secondary School Principals.

Diem, C.D. (2012). How the presence of a technologically supported library influences high school students' reading habits and skills. Global Advanced Research Journal of Library, Information and Archival Studies, 1(1), 001-005.

Foese, V. (1997). The relationship of school materials and resources to reading literacy: An international perspective. In: Lighthall, L., \& Haycock, K., (Eds.) Information rich but knowledge poor? Emerging issues for schools and libraries worldwide (pp. 283-303). Seattle, WA: International Association of School Librarianship.

Harris, J. H., \& Katz, L. G. (2001).Young investigators: The project approach in the early years. New York: Teachers College Press.

Moursund, D. (1999). Project-based learning using information technology. Eugene, OR: International Society for Technology in Education.

Newmann, S., Celano,D., Greco,A., \& Shue, P. (2001). Access for all: Closing the book gap for children in early education. Newark, DE: International Reading Education.

Thomas, J. W. \& Mergendoller, J. R. (2000). Managing project-based learning: Principles from the field. Paper presented at the Annual Meeting of the American Educational Research Association, New Orleans.

Thomas, J. W., Mergendoller, J.R., \& Michelson, A. (1999). Project-based learning: A handbook for middle and high school teachers. Novato, CA: The Buck Institute for Education.

Topping, K., Valtin, R., Roller, C., Brozo, W., \& Dionisio, M. L. (2003). Policy and practice implications of the program for international student assessment (PISA) 2000: Report of the International Reading Association PISA Task. Newark, US: International Reading Association.

Westwood, P. (2008). What teachers need to know about teaching methods. Camberwell, Victoria: Aces Press. 